\title{
COMMERCIAL LAW AND COMPANY LAW
}

\author{
Len Sealy"
}

\section{INTRODUCTION}

Nearly twenty years ago, when Lord Denning retired after having held high judicial office for the best part of four decades, I was asked to write a short piece for the journal of the Law Society of King's College, London. I reflected then that it had been a great stroke of good fortune for me to have spent so much of my teaching career in a period when our greatest innovator was in full cry, springing a fresh surprise every time that one opened the week's instalment of law reports. ${ }^{1}$ The students held him in special regard, not just because they admired the "bold spirit" who was never afraid to speak his mind and press the case for change, often with a mischievous disregard for the niceties of precedent, but perhaps even more because his lucid prose, full of short sentences and words of one syllable, made immediate sense to them and in their view made it quite unnecessary to read the judgements of his brethren - regardless sometimes of the fact that theirs was the majority opinion and his the dissent. ${ }^{2}$

Lord Denning began life on the bench as a divorce judge, before moving to the King's Bench Division. He did not ever sit in the Commercial Court or what is today the Companies Court. However, his influence on the commercial law of his day was immense, through the changes which he spearheaded both in the general law of contract and those more specifically affecting commercial law and practice. Although in the minds of most of us he is best remembered as the champion of the underdog - the

\footnotetext{
* SJ Berwin Professor Emeritus of Corporate Law, Cambridge

${ }^{1}$ Re-reading the piece, I do seem to have allowed myself to be somewhat carried away: "However arid the topic or hung-over the lecturer, however unsocial the teaching hour, one has only to mention the name to sense the quickening of interest; and the biros drive across the pages, desperate to ensure that not a syllable of wisdom is lost. And the lecturer, whether he endorses or dares to disown the opinions of the Master he is quoting, rides on a cloud, and briefly joins the immortals" (1980) 32 King's Counsel 29.

${ }^{2}$ The appeal of these qualities is not confined to students. As a compiler of casebooks in the two areas covered by this paper, I have found myself, time and again, selecting passages from the Denning judgement rather than those of his concurring colleagues, for reasons of sheer readability and not necessarily because his was in my view the best exposition of the law.
} 
consumer, the victim of bureaucracy, the deserted wife - his judgements in the commercial area show that he was every much as keenly aware of the special concerns of business and the importance its practitioners attach to certainty, speed and the absence of technicality. In company law, his role was limited to a dozen or so cameo appearances, each of them memorable in itself, but not really sufficient to justify any claim that he has left his own mark on the subject.

Although in what follows I shall attempt to evaluate Lord Denning's contributions to my fields of the law topic by topic, I have chosen also to group the cases in such a way as to highlight as well some of the characteristics which have marked him out as someone out of the ordinary, as man and as judge, during his long spell in office. Greatest above all of these qualities, I would say, has been the ability to sense a trend whose hour has come - sometimes twenty years or more ahead of the rest of us, as events have so often shown. ${ }^{3}$ But coupled with this has been an uncanny awareness of just how far to go: change which is too radical or too abrupt runs the risk of being rejected by a world which is not ready for it. ${ }^{4}$

In my own view, two of the most important milestones in his distinguished career date from relatively early days. The first is the notorious case of L'Estrange v. Graucob Ltd., in which the lady proprietor of a small-town teashop was held liable to pay in full for a machine which never worked properly because she had been conned into signing a document containing small print by which she waived all her statutory rights. ${ }^{5}$ The judgement became known as "the canvassers' charter" and was subsequently hawked around county courts all over the country by unscrupulous sellers.

I vividly remember Lord Denning confessing to a student audience that, to his embarrassment, he had been counsel for the successful plaintiff in $L^{\prime}$ Estrange v. Graucob and had been so shocked at the injustice of the decision that he had since spent much time and effort battling to obliterate the authority of that case and to create scope for the courts to cut down the

\footnotetext{
${ }^{3}$ The most striking example of this is his dissenting judgement in Candler v. Crane, Christmas \& Co. [1951] 2 K.B. 164. Not only was his view vindicated a dozen years later by the House of Lords in Hedley Byme \& Co. Ltd. v. Heller \& Partners Ltd. [1964] A.C. 465, but 27 years further on, when a later House of Lords was poised to disown Anns Y. Merton L.B.C. [1978] A.C. 628 and many of the cases which had followed it, no better basis could be found for a fresh start than the once-derided Denning dissent of forty years before: see Caparo Industries plc v. Dickman [1990] 2 A.C. 605 at 621-623, 636, 656-657.

${ }^{4}$ We must all surely recall his disarmingly modest words in Combe v. Combe [1951] 2 K.B. 215 at 219: "Much as I am inclined to favour the principle stated in the High Trees case, it is important that it should not be stretched too far, lest it should be endangered."

${ }^{5}$ [1934] 2 K.B. 394.
} 
effect of unreasonable exemption clauses. ${ }^{6}$ The second is his best-known ruling as a judge of first instance, High Trees, - not so much for what it decided, although that in itself has proved to be of immense significance, but because it set the pattern for so many of the innovations that were to come from his lively imagination: first, the perception of a legal need, a gap in the law, and a realisation that the time for change was ripe; then the identification of a slender thread of "authority" hidden in older case-law which ran contrary to the accepted precedents that appeared to stand in the way of reform; and finally the bold claim that the latter could be circumvented or disregarded, for reasons which are at first sight hard to justify and on further thought just as hard to dismiss. ${ }^{7}$ The importance of High Trees in my view is that it showed our iconoclast hero that, given the will, there could usually be found a way, and illustrated a technique for introducing reform which he was to hone and perfect in the years to come.

\section{COMMERCIAL LAW}

\section{The innovator}

I recall an occasion when Lord Denning was asked to name one single achievement for which he would most wish to be remembered by posterity, and he replied: "the Mareva injunction."

The Mareva case itself was the second in the sequence but carries the greater weight because the first, Nippon Yusen Kaisha v. Karageorgis, appears not to have been fully argued. ${ }^{9}$ The issue was, of course, whether the court would, in the face of many decades of settled practice to the contrary, grant an injunction to restrain a defendant from moving assets out of the jurisdiction at a time when the plaintiff had not yet established his right to proceed against those assets by getting a judgement in his favour. In each case the court, headed by Lord Denning, ruled that its discretionary jurisdiction was wide enough to empower it to do so, and granted the injunction. But in the Nippon case Lord Denning gave an added reason for making the change: the practice on the continent of Europe allowed such orders, and the time had come for us to fall into line. Over the next few years, Lord Denning was able to ensure that he was on the bench ${ }^{10}$ on a number of occasions when the scope of the new

\footnotetext{
${ }^{6}$ See infra $\mathrm{n} .22$ \& text.

${ }^{7}$ Central London Property Trust Ltd. v. High Trees House Ltd. [1947] K.B. 130.

${ }^{8}$ Cf. Denning, The Due Process of Law (Butterworths, 1980) (hereafter "Due Process") at p.134: "the greatest piece of judicial law reform of my time."

${ }^{9}$ Nippon Yusen Kaisha v. Karageorgis [1975] 1 W.L.R. 1093; Mareva Compania Naviera

S.A. v. International Bulkcarriers S.A. [1975] 2 Lloyd's Rep. 509.

10 "I ... have some say in the constitution of the court": Due Process at p. 7.
} 
procedure was discussed further: Rasu v. Perusahaan, ${ }^{11}$ when the issues were debated fully inter partes; The Siskina,${ }^{12}$ in which the new procedure was all but overthrown when his court was reversed by the House of Lords; Third Chandris Corporation v. Unimarine, ${ }^{13}$ where The Siskina was given a restricted interpretation and the Mareva injunction largely salvaged; and other cases where it was confirmed that Mareva relief lies against a defendant based in this jurisdiction, that it is available in a tort action for personal injuries, and so on. ${ }^{14}$

Alongside the achievement of the Mareva injunction must be ranked the Anton Piller order, which dates from the same period and which has had such a dramatic effect in the enforcement of intellectual property rights. ${ }^{15}$ By empowering an intending plaintiff on an application ex parte to search the premises of pirates and bootleggers without prior warning, they could be caught in flagrante delicto in possession of their illicit material before having any chance to get rid of it. Lord Denning proudly claims credit for his leading part in the cases which established this novel procedure. ${ }^{16}$

Perhaps the particular reason why Lord Denning ranks the establishment of the Mareva injunction as his greatest achievement (apart from its importance in practice) is that the innovation came about entirely through the efforts of the judiciary and was established in the face of arguments on all sides (and open rebuke from the House of Lords ${ }^{17}$ ) that this was a matter that should be only dealt with by the legislature. But his reply was always that important reforms could not wait, and that if change was due he had a duty to do something about it. ${ }^{18}$ And after the House of Lords in Miliangos adopted much the same approach to the question of awarding judgements in a foreign currency there was less reason for Lord Denning to feel any inhibitions about taking such a stance. ${ }^{19}$

\footnotetext{
"Rasu Maritima S.A. v. Perusahaan [1978] Q.B. 644.

${ }^{12}$ Siskina (Cargo Owners) v. Distos Compania Naviera S.A. [1979] A.C. 210 (C.A. and H.L.).

${ }^{13}$ Third Chandris Shipping Corporation v. Unimarine S.A. [1979] Q.B. 645.

${ }^{14}$ Lord Denning himself tells the full story in Due Process, Part 4.

${ }^{15}$ Anton Piller K.G. v. Manufacturing Processes Ltd. [1976] Ch. 55; cf. Ex parte Island Records Ltd. [1978] Ch. 122.

${ }^{16}$ Due Process, at pp.123-130.

${ }^{17}$ The Siskina, supra n.12.

${ }^{18}$ On more than one occasion he took his cue from a report of the Law Commission recommending reform, without waiting for action by the legislature: see, e.g. Liverpool City Council v. Irwin [1976] 1 Q.B. 319. His persistent attempts to introduce a remedy for the third-party beneficiary of a contract made between other parties, based on the Law Revision Committee's recommendation of 1937, are another example: see Denning, The Discipline of Law (Butterworths, 1979) (hereafter "Discipline") at p.289. His views were roundly condemned by Lord Simonds in Midland Silicones Ltd. v. Scruttons Ltd. [1962] A.C. 446. ${ }^{19}$ Miliangos v. George Frank (Textiles) Ltd. [1976] A.C. 443. (Miliangos itself drew support from the Court of Appeal's earlier judgement in Schorsch Meier G.m.b.H. v. Hennin [1975]
} 


\section{The internationalist and comparativist}

In the Mareva developments, Lord Denning openly took the view that English law should keep in step with developments in other jurisdictions. And he was also astute to anticipate, far sooner than most of us, how extensively the "incoming tide" of European Community law would find ways of permeating our traditional law. ${ }^{20}$ There are many instances in his judgements of his drawing on the laws of other countries to give inspiration or impetus to change which he considered was due. ${ }^{21}$

\section{The campaigner}

Of course, it was not always the case that Lord Denning succeeded in bringing about reform to the law by judicial means. His attempts to rewrite the law of mistake or to free contract law from the constraints of the doctrine of privity, for instance, did not receive wholehearted support. For more radical changes of this kind, nothing short of legislation is likely to be effective. But, as so often, he was simply ahead of his time in appreciating the need for reform; and it must be a source of some satisfaction for him to know that privity, for instance, did eventually come on to the Law Commission's agenda and that reform is in the air.

In some cases, and most notably in regard to exemption clauses, his endeavours bore fruit while he was still on the bench. From being counsel in L'Estrange v. Graucob to seeing the Unfair Contract Terms Act 1977 on the statute-book was, for him, a long and tortuous journey; but he was able, in his last judgement in this area (the George Mitchell case), to express satisfaction at the outcome and at the part that he and his fellow judges had played towards bringing it about. ${ }^{22}$ In this case he refers to the "secret weapon" (the "true construction of the contract") which, used "with great skill and ingenuity" could defeat any exemption clause which

Q.B. 416, in which Lord Denning and his brethren had "turned a blind eye" to House of Lords authority (Discipline at p.305).)

${ }^{20}$ H.P. Bulmer Ltd. v. J. Bollinger S.A. [1974] Ch. 401 at 418.

${ }^{21}$ See, e.g. Trendtex Trading Corporation v. Central Bank of Nigeria [1977] Q.B. 529 at $555-$ 556 , where he drew on the laws of several foreign countries in formulating a revised doctrine of sovereign immunity.

${ }_{22}$ George Mitchell (Chesterhall) Ltd. v. Finney Lock Seeds Ltd. [1983] Q.B. 284. On appeal, when the ruling was affirmed by the House of Lords, Lord Diplock paid a handsome tribute: "I cannot refrain from noting with regret, which is, I am sure, shared by all members of the Appellate Committee of this House, that Lord Denning M.R.'s judgement in this case ... is probably the last in which your Lordships will have the opportunity of enjoying his eminently readable style of exposition and his stimulating and percipient approach to the continuing development of the common law to which he has himself in his judicial lifetime made so outstanding a contribution." [1983] 2 A.C. 803 at 810 . 
would give rise to an unreasonable result. ${ }^{23}$ With the enactment of the Unfair Contract Terms Act 1977, "we reach, after long years, the principle which lies behind all our striving" - the test of reasonableness to which recourse could be had openly under the statute rather than by the more devious means used up until then.

\section{Judicial discretion and interventionism}

One does not need to study Lord Denning's judgements for long before discovering how strongly he felt the need for judges to have greater powers to intervene in a discretionary way in order to dispense better justice where the circumstances require it. The rigidity of many of the classifications established in the law was, to him, a tiresome obstacle; and so were many other traditional constraints, such as the necessity in matters of contract to have regard to the presumed intention of the parties. So we see him giving short shrift to the distinction between terms and "mere" representations; ${ }^{24}$ rejecting the "officious bystander" test as a yardstick for the implication of additional terms; ${ }^{25}$ bringing equitable doctrines in to supplement the common-law rules as to common mistake ${ }^{26}$ and waiver ${ }^{27}$ and freely using the rules of construction so as to make a contract to supply water at fixed rates for an unlimited period (which the ravages of inflation had made unprofitable) subject to an implied term that it was determinable on reasonable notice. ${ }^{28}$

Judicial techniques which enable the court to dispense discretionary justice, such as the use of the power to imply terms into a contract, can obviously strike at the very foundations of contract law if used too freely or irresponsibly. Although it must have come hard for him, this does seem to be a lesson which Lord Denning learnt early on in his dealings with commercial transactions, at least in the area of frustration. In the British Movietonews case Lord Denning, soon after his elevation to the Court of

\footnotetext{
${ }^{23}$ [1983] Q.B. 284 at 297.

${ }^{24}$ See generally Discipline at pp.270-276.

${ }^{25}$ Liverpool City Council v. Irwin [1976] 1 Q.B. 319: see Discipline at pp.37-40. But in this judgement he was held to have strayed too far from orthodoxy by the House of Lords (who, however, upheld the Court of Appeal's actual decision on the point): [1977] A.C. 239.

${ }^{26}$ Solle v. Butcher [1950] 1 K.B. 671.

${ }^{27}$ In Discipline at pp.209-214, Lord Denning describes how the High Trees principle was developed, particularly in relation to commercial transactions, so as first to get rid of the necessity for writing under the (then) Sale of Goods Act (Plasticmoda Societa per Azioni v. Davidsons (Manchester) Ltd. [1952] 1 Lloyd's Rep. 527) and, secondly, to overcome the limitations of the common law doctrine of waiver by eliminating the need for a party to have actual knowledge of a breach of contract before the doctrine could apply (Panchaud Frères S.A. v. Etablissements General Grain Co. [1970] 1 Lloyd's Rep. 53 - "probably the case most frequently cited in the Commercial Court, although the text-book writers hardly notice it").

${ }^{28}$ Staffordshire A.H.A. v. South Staffordshire Waterworks Co. [1978] 1 W.L.R. 1387.
} 
Appeal, sought to restate the doctrine of frustration by saying: "In these frustration cases,... the court really exercises a qualifying power ... in order to do what is just and reasonable in the new situation."29 The House of Lords would have none of this, and not only reversed the court below, but administered a sharp rebuke, emphasising that "No court has an absolving power." Although in other contexts Lord Denning was often not deterred from continuing to press a heterodox line of thought despite the displeasure of the Lords, we do not see in his later cases any attempt to reassert the "just and reasonable" basis for the doctrine of frustration in commercial cases. ${ }^{30}$ Indeed, generally speaking, ${ }^{31}$ he showed a good deal of restraint in not seeking to erode the principle of freedom of contract in transactions between commercial parties, and a keen appreciation of the businessman's priorities and the traditions of the Commercial Court. ${ }^{32}$

\section{Statutory interpretation}

Hand-in-hand with Lord Denning's concern to see greater scope for discretionary intervention in many areas of law was his enthusiastic endorsement of a purposive approach towards statutory interpretation. $\mathrm{He}$ tells about it in The Discipline of Law. ${ }^{33}$ For this he was roundly condemned by the House of Lords: what he was doing was " a naked usurpation of the legislative function under the thin disguise of interpretation." ${ }^{34}$ But Lord Denning remained unrepentant and, with a degree of backing from the report of the Renton Committee, ${ }^{35}$ continued to take the same approach in later years.

\section{COMPANY LAW}

\section{Corporate personality}

As noted above, Lord Denning's reported company law judgements are few in number but even so, in many ways memorable. Remarkably, one or two passages continue to be cited - perhaps for the sheer vividness of his prose - even though they are now considered as being of doubtful authority. Foremost among these are observations which he made in the

\footnotetext{
${ }^{29}$ British Movietonews Ltd. v. London \& District Cinemas Ltd. [1951] 1 K.B. 190 (C.A.); [1952] A.C. 166 (H.L.).

${ }^{30}$ See, e.g., Intertradex S.A. v. Lesieur Torteaux S.A.R.L. [1978] 2 Lloyd's Rep. 509.

${ }^{31}$ Not, however, in the battle to have unfair exemption clauses outlawed: commercial considerations seem to have taken second place in cases like Harbutt's "Plasticine" Ltd. v. Wayne Tank \& Pump Co. Ltd. [1970] 1 Q.B. 447 and Photo Production Ltd. v. Securicor Transport Ltd. [1978] 1 W.L.R. 856.

${ }^{32}$ See Due Process at p.135, and the cases cited supra n.30 and infra n.55.

${ }^{33}$ Discipline at pp.9-22. See also Phonogram Ltd. v. Lane, infra $\mathrm{n} .43$ \& text.

${ }^{34}$ Nimmo v. Alexander Cowan \& Sons Ltd. [1968] A.C. 107 at 130.

${ }^{35}$ The Preparation of Legislation, Cmnd. 6053 (1975), para. 19.2.
} 
context of "lifting the veil" of incorporation. Of course, this is just the kind of area tailor-made for discretionary intervention in the broader interests of "justice" that he as a judge found irresistible. No-one would quibble with his condemnation of Dr. Wallersteiner's manipulation of his Liechtenstein companies:

"I am quite clear that they were just the puppets of Dr Wallersteiner. He controlled their every movement. Each danced to his bidding. He pulled the strings. No one else got within reach of them. ... I am of the opinion that the court should put aside the corporate veil and treat these concerns as being his creatures. ${ }^{, 36}$

In Littlewoods Mail Order Stores Ltd. v. McGregor Lord Denning declared with gusto that "the courts can, and often do, pull off the mask" of incorporation. ${ }^{37}$ But it was in D.H.N. Food Distributors Ltd. v. Tower Hamlets L.B.C. ${ }^{38}$ that the disregard of the corporate veil reached an alltime high, from which we can now see courts in all the Commonwealth jurisdictions in steady retreat ${ }^{39}$ Here we had a group of three companies which "might be called the 'Three in one.' Alternatively, the 'One in three.' One group of three companies." Lord Denning, drawing support from a "general tendency to ignore the separate legal entities of various companies within a group, and to look instead at the economic entity of the whole group," perceived by Professor Gower, ${ }^{40}$ declared that the three companies should be treated as one so that they would not be deprived of statutory compensation for disturbance. Twenty years on, this decision is in universal disfavour, but it continues to hold a key place in the textbooks and students' first-term essays, and even to be cited hopefully (but invariably in vain) by counsel.

We see similar graphic language in his exposition of the "alter ego" doctrine in terms which, drawing on a parallel with the human body, contrasted a company's "brain and nerve centre" with the "hands which

\footnotetext{
${ }^{36}$ Wallersteiner v. Moir [1974] I W.L.R. 991 at 1013. The niceties of the principle of corporate personality were twice ignored by Lord Denning (citing Dicey and Maitland) in Willis v. Association of Universities of the British Commonwealth [1965] Q.B. 141, once to accord quasi-corporate status to the unincorporated association and, secondly, to identify that body with a chartered company which later took over its functions.

${ }^{37}$ [1969] 1 W.L.R. 1241 at 1254.

38 [1976] 1 W.L.R. 852 at $857,860$.

${ }^{39}$ See, e.g. Woolfson v. Strathclyde Regional Council 1978 S.L.T. 159; Adams v. Cape Industries plc [1990] Ch. 433; Re Securitibank Ltd. (No. 2) [1978] 2 N.Z.L.R. 136 at 158; Industrial Equity Ltd. v. Blackburn (1977) 137 C.L.R. 567.

${ }^{40}$ Modern Company Law, (Sweet \& Maxwell, 3rd ed., 1969) at p. 216.
} 
hold the tools" ${ }^{, 41}$ - language which, once again, despite having been given a narrow interpretation by the House of Lords, ${ }^{42}$ continues to occupy a major place in any exposition of the subject.

\section{Preincorporation contracts}

In Phonogram Ltd. v. Lane an English court was asked for the first time to give an interpretation to the E.C. First Company Law Directive's provision dealing with contracts purportedly made on a company's behalf prior to its incorporation. ${ }^{43}$ This provision had been incorporated into our domestic law by the European Communities Act 1972, section 9(2). The choice was between giving a restrictive or a purposive meaning to the statutory text - the first having some support from the French version of the Directive and the second from our own Act. Lord Denning was able to achieve a satisfying "double" by taking the purposive line (as was his wont) and flying the patriotic flag at the same time, declaring his preference for the English rather than the French text.

\section{The minority shareholder}

In Scottish Co-operative Wholesale Association Ltd. v. Meyer, this time from the House of Lords, Lord Denning once again had an opportunity to launch a new piece of legislation on its way with a purposive shove. ${ }^{44}$ This was the first time a case (at least, a reported case) had come before the court on section 210 of the Companies Act 1948 (now section 459 of the $1985 \mathrm{Act}$ ) - which empowers the court to grant discretionary relief where minority shareholders have been the victim of "oppression" or "unfairly prejudicial conduct." Given an underdog plaintiff and an openended discretion, it is not any great surprise that he went out of his way to endorse the new jurisdiction in enthusiastic terms, and in the case itself see the minority shareholders fully compensated. Unfortunately, his junior brethren who sat in the Chancery courts in the sixties and seventies did not share his empathy with aggrieved minority shareholders or his enthusiasm for unfettered discretionary powers, and the consequence was that section 210 failed in its purpose and had to be totally recast in 1980 .

Mr. Moir, the minority shareholder in the two Wallersteiner cases, also received generous treatment at the hands of Lord Denning. ${ }^{45}$ The first, in which Wallersteiner endeavoured to stifle inquiries into the management of his corporate group by issuing a gagging writ, is best known for Lord

\footnotetext{
${ }^{41}$ H.L. Bolton (Engineering) Ltd. v. T.J. Graham \& Sons Ltd. [1957] 1 Q.B. 159 at 172.

${ }^{42}$ Tesco Supermarkets Ltd. v. Nattrass [1972] A.C. 153.

${ }^{43}$ [1982] Q.B. 928.

44 [1959] A.C. 324.

${ }^{45}$ Wallersteiner v. Moir [1974] I W.L.R. 991; Wallersteiner v. Moir (No. 2) [1975] Q.B. 373: see supra n.36.
} 
Denning's observations on lifting the corporate veil, referred to above. In the second, when Moir had at last got a foot across the threshold and been able to file pleadings to commence a derivative action, his impecuniosity was proving a major obstacle. The Court of Appeal gave its blessing to the introduction of the "Wallersteiner order," by which the company which is nominally a defendant to the proceedings but in reality a surrogate plaintiff is ordered to meet the costs of the shareholder on whose initiative the action has been brought. Indeed, Lord Denning himself would have gone further, and made the shareholder's derivative suit a special exception to the rule (of which he himself was a strong supporter) which has traditionally opposed the right of counsel to appear on a contingency-fee basis.

\section{Agency and the interested director}

Ever since Royal British Bank v. Turquand in 1856, company law has had rules which relieve persons who deal with a company from being under any obligation to check whether the company's internal procedures have been duly adhered to. ${ }^{46}$ But these traditional rules have no application where the person concerned is an "insider," such as a director, who can at least in theory - check this sort of thing out for himself. In HelyHutchinson v. Brayhead Ltd. a deal had been done between Brayhead's chairman (from all accounts, a dominant, larger-than-life personality) and Hely-Hutchinson in which the former had shown scant regard for constitutional proprieties. ${ }^{47}$ The company, pleading that the chairman had exceeded his authority, sought to disown its obligations to HelyHutchinson, who appeared not to be protected by Turquand because he had recently been made a director of Brayhead, and so was an insider. Moreover, he himself had not disclosed his interest to the board, as both the Companies Act and Brayhead's articles required. Despite these and other seeming obstacles, ways were found by Lord Denning and his brethren to distinguish the earlier authorities so that the deserving HelyHutchinson was not left whistling for his money. The difference here, it was said, was that Hely-Hutchinson was not acting as a director in this particular transaction: he was on the other side of the negotiating table. So regard was had to the realities of the situation rather than to the technical fact that the man happened to be a director - an argument which quite certainly would not have swayed the House of Lords which decided the leading case twenty years earlier. ${ }^{48}$ The non-disclosure point, too, was held not to stand in Hely-Hutchinson's way, Lord Denning advancing a view which was not shared by a later Court of Appeal in Guinness plc v.

\footnotetext{
${ }^{46}$ (1856) 6 E. \& B. 327.

${ }^{47}$ [1968] 1 Q.B. 549.

${ }^{48}$ See Morris v. Kanssen [1946] A.C. 459.
} 


\section{COMMERCIAL \& COMPANY LAW}

Saunders, ${ }^{49}$ but accepted as correct when that case went to the House of Lords. $^{50}$

\section{D.T.I. inspectors' inquisitorial powers}

In two cases involving Mr. Robert Maxwell, later to become a figure of international notoriety, Lord Denning appears in what at first sight is a surprisingly hawkish light; but I believe that we can understand the reason for this. ${ }^{51}$ Mr. Maxwell and his fellow-directors had been made the subject of an investigation by inspectors appointed by the Secretary of State, and they had refused to answer questions unless they were first given assurances that, in effect, the proceeding would be conducted as if it were a judicial inquiry. They received little sympathy from Lord Denning's court: the inspectors were expected to act fairly, but were not to be constrained by rules of law. In effect, the directors were sent packing and told to face up to their responsibilities, like so many schoolboys. I think that in taking this view Lord Denning would have been all too conscious of the exposed position which he had found himself in some years previously in the Profumo inquiry, where in a rather similar way he was required to hold an inquisition following a major public scandal, without any clear directions as to how the matter should be handled. His report would inevitably involve findings, possibly of a criminal nature, against persons who might reasonably protest that they had not had the protection of a criminal trial. He had to get on with the task as best he could, keenly aware that whatever he did was bound to attract criticism; and so understandably he identified with the D.T.I. inspectors rather than with the citizens summoned to appear before them.

\section{Role of the company secretary}

When the precedents stand in the way of change, the bold spirit must sometimes confront them head on. Faced on the one hand with a fraudulent company secretary who had exposed his company to commitments in excess of his authority, and on the other with precedents to the effect that "A secretary is a mere servant; his position is to do what he is told, and no person can assume that he has any authority to represent anything at all," 52 Lord Denning's response was: "Times have changed. A

\footnotetext{
${ }^{49}$ [1988] 1 W.L.R. 863.

${ }^{50}$ [1990] 2 A.C. 663 . (Failure to comply with the statutory obligations of disclosure has criminal sanctions but no civil consequences.)

${ }^{51}$ Re Pergamon Press Ltd. [1971] Ch. 388; Maxwell v. D.T.I. [1974] Q.B. 523. See also Norwest Holst Ltd. v. Secretary of State for Trade [1978] Ch. 201, in which the Secretary of State was held not bound to observe the rules of natural justice in determining whether or not to appoint inspectors.

${ }^{52}$ Barnett v. South London Tramways Co. (1887) 18 Q.B.D. 815 at 817.
} 


\section{DENNING LAW JOURNAL}

company secretary is a much more important person nowadays. ... He is no longer a mere clerk. He regularly makes representations on behalf of the company and enters into contracts on its behalf which come within the day-to-day running of the company's business. So much so that he may be regarded as held out as having the authority to do such things on behalf of the company." 53

\section{CONCLUSION}

The company law cases to which I have referred are typical illustrations of Lord Denning's contribution to the law of his and our time. Company law has its roots in the nineteenth century and has been served by Chancery judges largely of a conservative and risk-averse disposition. There was scope for a breath or two of fresh air, and he took the opportunity to give a lead in the relatively few cases that came before him.

In commercial law, although some of his judgements have not escaped criticism, ${ }^{54}$ it is generally true to say that he was keenly appreciative of the important part that English law, with its laissez-faire traditions, continues to play in the world of merchandising and shipping, banking and insurance, and his rulings commonly reflect this awareness. ${ }^{55}$ And if, of all his contributions, he himself would single out the Mareva injunction to have as a memorial, I am sure that few practitioners in the Commercial Court would wish to disagree.

\footnotetext{
${ }^{53}$ Panorama Developments (Guildford) Ltd. v. Fidelis Furnishing Fabrics Ltd. [1971] 2 Q.B. 711 at 716.

${ }^{54}$ See, e.g. United Dominions Trust Ltd. v. Kirkwood [1966] 2 Q.B. 431 (what is a bank?); Van Lynn Developments Ltd. v. Pelias Construction Co. Ltd. [1969] 1 Q.B. 607 (notice of assignment).

${ }^{55}$ See, e.g. the Intertradex case, supra n.30 (no frustration of commodity sale); TeheranEurope Ltd. v. S.T. Belton (Tractors) Ltd. [1968] 2 Q.B. 545 (implied terms as to quality); Trans Trust S.P.R.L. v. Danubian Trading Co. Ltd. [1952] 2 Q.B. 297 and Pavia \& Co. S.p.A.v. Thurmann-Nielsen [1952] 2 Q.B. 84 (opening of credit); Arab Bank Ltd. v. Ross [1952] 2 Q.B. 216 (irregular indorsement); British Crane Hire Corpn. Ltd. v. Ipswich Plant Hire Ltd. [1975] Q.B. 303 (incorporation of usual trade terms).
} 